\title{
Transformational change: creating a safe operating space for humanity
}

\author{
$\underline{\text { Clive A. McAlpine }}^{1}, \underline{\text { Leonie M. Seabrook }}^{1}, \underline{\text { Justin G. Rvan }}^{1}, \underline{\text { Brian J. Feenev }}^{1}, \underline{\text { William J. Ripple }}^{2}, \underline{\text { Anne H. Ehrlich }}^{3}$ and Paul R. \\ Ehrlich $^{3}$
}

\begin{abstract}
Many ecologists and environmental scientists witnessing the scale of current environmental change are becoming increasingly alarmed about how humanity is pushing the boundaries of the Earth's systems beyond sustainable levels. The world urgently needs global society to redirect itself toward a more sustainable future: one that moves intergenerational equity and environmental sustainability to the top of the political agenda, and to the core of personal and societal belief systems. Scientific and technological innovations are not enough: the global community, individuals, civil society, corporations, and governments, need to adjust their values and beliefs to one in which sustainability becomes the new global paradigm society. We argue that the solution requires transformational change, driven by a realignment of societal values, where individuals act ethically as an integral part of an interconnected society and biosphere. Transition management provides a framework for achieving transformational change, by giving special attention to reflective learning, interaction, integration, and experimentation at the level of society, thereby identifying the system conditions and type of changes necessary for enabling sustainable transformation.
\end{abstract}

Key Words: behavioral change; connectedness; innovative leadership; societal values; transformational change; transition management

\section{INTRODUCTION}

The cumulative effect of human activities, driven by human population growth and consumption patterns, is exceeding the sustainable limits of the Earth's biosphere (Rockström et al. 2009, Steffen et al. 2015). There is strong evidence that the Earth is approaching, or may already have passed, one or more tipping points (Lenton et al. 2008, Barnosky et al. 2012, Lenton 2012), leading to major problems for civilization. These are related to how humans are rapidly damaging ecological life-support systems, especially as related to climate change (IPCC 2013, 2014), extinctions of biological populations and species (Pimm et al. 2014), including the largest carnivores at the top of the food web (Ripple et al. 2014a), wholesale loss of diverse ecosystems, global spread of invasive species (Crowl et al. 2008) and toxic substances (Cribb 2014). There is an increasing global struggle for vital supplies of energy mineral resources, and arable land (Klare 2012, Ehrlich and Ehrlich 2013, Barnosky et al. 2014). At some point in the not-too-distant future, environmental changes will compel adjustments in how societies function, forcing many people to reassess business as usual (Moore and Nelson 2010, Barnosky et al. 2014). To prevent these changes being catastrophic, the global community must begin now to develop more sustainable alternatives in which humanity might operate within the limits of rapidly changing and increasingly variable natural systems, with associated adjustments in social systems. The critical question then is: how to initiate self-correcting feedback loops that will enable the transition to a more sustainable and equitable society?

\section{UNSUSTAINABLE PRESSURES ON THE EARTH SYSTEM}

The so-called Anthropocene has passed through two stages marked by increasing impacts on the biosphere (Crutzen 2006). The first, from the late $1700 \mathrm{~s}-1945$, started with the harnessing of steam power and thereafter a rapid increase in mechanization and concurrent demand for energy resources. Human population growth increased because of improved public health and use of nonrenewable natural resources (Fig. 2 in Steffen et al. 2007), placing greater strains on the biosphere. The second stage, from 1945 to the present, was marked by human domination of Earth increasing at an unprecedented rate (Steffen et al. 2011). The core beliefs of this era are the continuation of material progress and economic growth, with the limitations of nature overcome by technology; and the primacy of the individual in competition with other individuals for a share in the wealth derived from nature (Hamilton 2010). These values are expressed through institutions such as political parties, financial systems, trade agreements, and private equity investment funds. Because of the multiple levels of interaction and mutual financial reward for many individuals from the "market knows best" belief system, these core values are further reinforced and imbued with an entrenched inertia, even though many question them as a route to widespread human wellbeing (Ehrlich and Ornstein 2010). The growth of emerging market economies such as China and India is further accelerating industrial production, consumption, and pollution on a global scale, but there also is an increasing gap between the rich and poor within and between countries. The top $1 \%$ of wealthiest people in the world, who account for almost $15 \%$ of the world income, and the middle classes of the emerging market economies, seem to be the main winners of economic globalization (Milanovic 2012). The losers include many people in Africa, and in some Latin American and post-Communist countries. The greatest income disparities are due to income gaps between nations rather than within nations, with nationality explaining over $50 \%$ of the variation in global incomes (Milanovic 2012).

Society is now at the beginning of the third stage of the Anthropocene (Crutzen 2006, Steffen et al. 2007, 2011), and close to the point where people must either become stewards of the Earth system, or gamble on unproven and potentially extremely dangerous geoengineering fixes to climate change with likely deleterious effects on the Earth's atmospheric processes and

${ }^{1}$ The University of Queensland, School of Geography, Planning and Environmental Management and National Environmental Decisions Research Hub, Brisbane, Australia, ${ }^{2}$ Department of Forest Ecosystems and Society, Oregon State University, Corvallis, Oregon, ${ }^{3}$ Center for Conservation Biology, Department of Biology, Stanford University, Stanford, California 
hydrological system (Matthews and Caldeira 2007, Hamilton 2013, Tilmes et al. 2013). The probability of catastrophic climate change is becoming more likely because of increasing greenhouse gas emissions from the burning of fossil fuels (World Bank 2012, Hansen et al. 2013, IPCC 2014), deforestation (Pielke et al. 2011), and the production and consumption of meat, especially from ruminants (Ripple et al. 2014b). The future remains uncertain because population and economic growth are decoupled from the externalities they create and continue to drive accelerating environmental degradation and loss of biodiversity (Daly 2005, 2014, Meadows et al. 2004, Pimm et al. 2014).

The world urgently needs counterbalancing mechanisms (Meadows 2008) to redirect global society toward a more sustainable future: one that moves the importance of intergenerational equity and environmental sustainability to the top of the political agenda and to the core of personal and societal belief systems (World Commission on Environment and Development 1987, Meadows et al. 2004). This will require major adjustments to social and economic systems, and incur immediate costs. However, although expensive and potentially creating upheaval in economic and social systems, early interventions are essential to avoid a real risk of economic, social, and environmental collapse (Brown 2011, World Bank 2012). Early interventions involve radically reducing environmental pressures and building resilience and adaptive capacity in social-ecological systems (Walker et al. 2004, Folke 2006, Olsson et al. 2006).

Science and technology have important roles in addressing environmental problems, but they alone cannot solve them. The 1992 Population Summit of the World's Scientific Academies recognized that science and technology may not be able to prevent either irreversible degradation of the environment or continued poverty for much of the world (National Academy of Sciences USA 1993). To have any effect on how society operates in terms of sustainability requires a transformation of human behavior rather than "fiddling around the edges" (Fischer et al. 2012) or "muddling through" (Lindblom 1959). This necessitates a realignment of societal values, i.e., the ideas, motivations, and actions of the actors in the system (Meadows et al. 2004, Moore and Nelson 2010). Achieving equitable, sustainable solutions involves a fundamental shift away from the view of humans as isolated agents in a competitive world, to one where individuals know themselves to be an integral part of an interconnected society and biosphere (Ehrlich et al. 2012). It particularly emphasizes a role where the individuals accept that they are responsible for creating a caring and sustaining social environment in which we all must live.

\section{TRANSFORMING SOCIETAL VALUES}

Transformational change in societal values needs to occur at three levels by: (1) being responsible and ethical in our dealings with other people and our environment; (2) better integrating ourselves into our communities; and (3) reconnecting with and valuing nature.

Personal integrity is at the core of behavioral change in individuals and ultimately societal transformation. Integrity builds a sense of purpose and conviction, which, combined with respect for others and personal responsibility, promotes ethical behavior. These qualities are currently lacking in many institutions (both private and public) and political systems today (Meadows et al. 2004,
Fischer et al. 2012). The power of personal integrity is that this motivation transcends utilitarian calculation, whereby individuals do not act because they believe that their personal action does not change the world. What can this mean for individuals? It means an active decision to reduce one's environmental footprint through actions such as restricting reproduction to "replacement level" (Murtaugh and Schlax 2009), minimizing fossil fuel use (World Bank 2012, Hansen et al. 2013), reducing meat consumption, especially from ruminants (Ripple et al. 2014b), and generally reducing levels of material consumption. Collectively, individual actions can make a huge difference.

This leads to our second point: the need to build strong, interconnected communities, where compassion, mutual aid and cooperation are the norm (Meadows et al. 2004). The ability of organizational groups to generate creative solutions to problems has been recognized in business for over 20 years (Wenger 2000), and now also in wider social communities in real or virtual space (Amin and Roberts 2008). There is a clear need for broader economic and political changes, such as removing harmful economic subsidies or incentives that lead to unsustainable decision making, and raising public understanding of environmental issues. However, it also requires recognizing that the human value system is currently unsustainable, and that through individual behavioral change, societies ultimately can become more caring and sustainable. This requires a change in emphasis from personal goals linked to a higher material standard of living to a lifestyle that values equitable, sustainable community values in conjunction with the development of individual aspirations. Perhaps an immediate goal here is for people to donate a proportion of their time to society, for instance, by participating in community activities, caring for the local environment, connecting with the elderly, or building strong neighborhood networks.

Finally, at an even larger scale, connectedness is a core value of becoming a globally responsible citizen. It is multifaceted, with actions at the local scale contributing to improving the local environment and community, while maintaining a strong global awareness of the need for better, more resilient life-support systems (Arnocky et al. 2007). Connectedness motivates individuals and communities to conserve and restore local ecosystems, to be aware of the environmental impacts of their lifestyle and behavior, and ultimately to strive toward reducing their ecological footprint on the planet. It is also highly beneficial to the individual, irrespective of the scale of one's actual physical effect on the environment (Arnocky et al. 2007).

Despite the highly commercialized focus of westernized societies, the values outlined above are latent in many cultures, and often come to the fore as responses to emergencies when the problem is immediate, real, and tangible. The beneficial actions of likeminded individuals can lead society toward sustainable futures and are a key plank for transformation. These values also offer a way to achieve ecological sustainability in the face of what Gardiner (2011) calls the "perfect moral storm" of ecological sustainability, that is, how to deal with the tragedy of the commons across space and time.

\section{ACHIEVING TRANSFORMATIONAL CHANGE}

There are three feasible ways of changing individual behaviour: (1) coercion by social stigma or legal sanction; (2) change of mind, 
being convinced intellectually that a broader definition of selfinterest is required; and (3) change of motivation, coming to feel a sense of being part of the "web of life" and having a sense of self and unity with others and the global environment.

Coercion and regulation can work in some instances, but the drawback is that they are imposed from an external source and are rarely adaptive or suitably flexible at the local level. Social stigma sends the wrong message from the community, increasing fear and division. Change of mind is being achieved within some parts of society, including in the scientific community and various institutions, and among concerned individuals. It is potentially more effective than coercion because there is acknowledgement of the problem, but still may not lead to behavioral change by a significant number of people. Simply providing more information, or more accurate information, does not, by itself change behavior, though good information is certainly important (Boykoff and Yulsman 2013). Obviously there is a role for governments to educate the public on issues that are larger than the individual in scope, but the government must be willing to embrace change and be brave enough to adhere to longer term policies that may be expensive up front and take years to come to fruition (Gardiner 2011).

Change of motivation is real and achievable, but will come through personal belief rather than through rational understanding. There are several issues that this pathway of behavioral change must overcome: (1) it is partially reliant on a rational change of mind; (2) the persistence of belief within an individual means one tends to seek information that supports current beliefs while ignoring discomfiting information (Weiten 1994); and (3) to overcome the persistence of nonsustainable current beliefs, the weight of evidence must be obvious, imminent, and significantly threatening to challenge these entrenched beliefs. If evidence is not pressing enough for daily lives to be abruptly and significantly changed on a large scale, particularly where the basic needs of individuals are not directly under threat, then beliefs may not necessarily be reconsidered.

There is an urgent need to change our society, particularly because of impending and potentially catastrophic climate disruption (Hansen et al. 2013) and degradation of ecological life-support systems. The global community, i.e., individuals, civil society, corporations, and governments, collectively need to change their values and belief systems so that global sustainability becomes the new reality (Planet Under Pressure 2012). This requires a fundamental shift in human behavior, to live more ethically and efficiently and to radically rethink the concept of progress and economic development in our societies. It requires a sense of urgency to collectively work toward solutions that will make a real difference in people's lives and promote human dignity for all. We are all part of one planet; our well-being depends on working together for a sustainable, more equitable society.

There is a growing understanding that building resilience and adaptive capacity are not enough to avoid societal collapse (Meadows et al. 2004, Butzer 2012, Pearson and Pearson 2012). Transformational change is a formidable challenge but is necessary. Transformation requires proactively changing the structures and processes when conditions make the existing socialecological system untenable (Walker et al. 2004). It requires constructing self-correcting feedback loops based on a shared vision of global sustainability, building networks based on a common purpose, learning new ways of doing things, and acting ethically and compassionately (Meadows et al. 2004). There is an increasing concern among those people who understand the scale of current environmental change about the potentially disastrous consequences of climate change, and the institutional and societal inertia in addressing the problem. Societies need to learn from history (Diamond 2005). In a historical analysis, Butzer (2012) concludes that the collapse of past civilizations was a consequence of multiple factors, reinforced by various feedbacks and partly balanced by resilience, with societal factors such as ideological differences and institutional inertia more important than environmental factors.

Transformative change can unfold in many different ways, depending on the system dynamics. There is an increasing recognition that alternatives to top-down governmental control for governing social-ecological systems are needed (Gunderson et al. 1995, Olsson et al. 2006). Transition management provides a framework for achieving transformational change, exploring new opportunities and systems of governance and management, and developing strategies to identify alternatives (Loorbach 2010). As with the adaptive cycle of resilience theory (Holling and Gunderson 2002, Walker et al. 2004), transition management is based on complex adaptive systems theory, with "transitions" being multilevel, multiphase processes for achieving long-term (at least 25 years) structural change in society (Loorbach 2010). Transition management gives special attention to reflective learning, interaction, integration, and experimentation at the level of society. Its conceptual foundations are at the microlevel, and have been empirically tested in water resource management in the Netherlands and Belgium (Loorbach 2010). One limitation is a failure to systematically reflect on interplay with the macrolevel, such as overall political structures or societal power relations, which may reduce the viability of governance ideas stemming from transition management processes (Voß and Bornemann 2011). Ferguson et al. (2013) propose integrating transition theory with the adaptive cycle of resilience theory (Holling and Gunderson 2002), to create a more a multilevel systemic framework for analyzing the dynamics of transformative change. The addition of institutional theory provides a building block for identifying which type of multilevel mechanisms are likely to be most effectively employed, through strategic initiatives, to enable a transition toward a desired future.

Changing normative societal values is critical for achieving transformational change. Old suspicions, conflicting interests, a narrow focus, and lack of trust can derail open discussion and lead to failure. Governments and self-interest groups often resist change because they cannot control or predict the outcome and fear losing power and influence. There are two key elements that make transitions more likely to overcome these system constraints (Olsson et al. 2006). First, is the existence of informal networks which link different groups. Informal "social" networks allow freer exchange of ideas than those limited by agency rules (Meadows et al. 2004). The second is the emergence of innovative leaders who can align people, motivate and inspire them, reconceptualize issues, generate and integrate different ideas, and connect different networks (Olsson et al. 2006). 


\section{CONCLUSION}

The future of the modern civilization is increasingly uncertain. Most ecological and environmental scientists recognize the enormity of the predicament society faces, and the consequences of not changing how societies around the world operate. This paper is a call to action for fellow ecologists and environmental scientists to participate in the transition to a more equitable, sustainable society. This requires a stronger engagement among scientists in the codesign, coproduction, knowledge sharing, and in the broader dialogue of developing innovative alternative futures in transition management. Ecological and environmental scientists need to present a united front, a convincing message, and strong leadership in building collaboration and knowledge, first within academic communities and with other disciplines, such as social scientists, political scientists, humanities, and economists, and then across networks of family, friends, and wider social and business networks. There are many moral arguments for doing what is right and for meeting obligations to achieve a sustainable biosphere that ensures the welfare of future generations (Moore and Nelson 2010). Living and acting with integrity, as members of communities and strongly connected with nature, will help protect Earth's life support systems, and at the same time deliver the rewarding cobenefits of happiness and personal well-being.

Responses to this article can be read online at: http://www.ecologyandsociety.org/issues/responses. $\mathrm{php} / 7181$

\section{Acknowledgments:}

We thank Michael P. Nelson, Nathalie Butt, and Tiffany Morrison for comments on an early draft of this paper. The constructive comments of the subject editor and an anonymous reviewer greatly improved the manuscript. Clive McAlpine is supported by an Australian Research Council Future Fellowship.

\section{LITERATURE CITED}

Amin, A., and J. Roberts. 2008. Knowing in action: beyond communities of practice. Research Policy 37:353-369. http://dx. doi.org/10.1016/j.respol.2007.11.003

Arnocky, S., M. Stroink, and T. DeCicco. 2007. Self-construal predicts environmental concern, cooperation, and conservation. Journal of Environmental Psychology 27:255-264. http://dx.doi. org/10.1016/j.jenvp.2007.06.005

Barnosky, A. D., J. H. Brown, G. C. Daily, R. Dirzo, A. H. Ehrlich, P. R. Ehrlich, J. T. Eronen, M. Fortelius, E. A. Hadly, E. B. Leopold, H. A. Mooney, J. P. Myers, R. L. Naylor, S. Palumbi, N. C. Stenseth, and M. H. Wake. 2014. Scientific consensus on maintaining humanity's life support system in the 21st century: information for policy makers. Anthropocene Review 1:78-109. http://dx.doi.org/10.1177/2053019613516290

Barnosky, A. D., E. A. Hadly, J. Bascompte, E. L. Berlow, J. H. Brown, M. Fortelius, W. M. Getz, J. Harte, A. Hastings, P. A. Marquet, N. D. Martinez, A. Mooers, P. Roopnarine, G. Vermeij, J. W. Williams, R. Gillespie, J. Kitzes, C. Marshall, N. Matzke, D.
P. Mindell, E. Revilla, and A. B. Smith. 2012. Approaching a state shift in Earth's biosphere. Nature 486:52-58. http://dx.doi. org/10.1038/nature11018

Boykoff, M. T., and T. Yulsman. 2013. Political economy, media, and climate change: sinews of modern life. Wiley Interdisciplinary Reviews: Climate Change 4:359-371. http://dx.doi.org/10.1002/ wcc. 233

Brown, L. R. 2011. World on the edge: how to prevent environmental and economic collapse. Earthscan, Washington, D.C., USA.

Butzer, K. W. 2012. Collapse, environment, and society. Proceedings of the National Academy of Sciences 109:3632-3639. http://dx.doi.org/10.1073/pnas.1114845109

Cribb, J. 2014. Poisoned planet: how constant exposure to manmade chemicals is putting your life at risk. Allen and Unwin, Crows Nest, New South Wales, Australia.

Crowl, T. A., T. O. Crist, R. R. Parmenter, G. Belovsky, and A. E. Lugo. 2008. The spread of invasive species and infectious disease as drivers of ecosystem change. Frontiers in Ecology and Environment 6(5):238-246. http://dx.doi.org/10.1890/070151

Crutzen, P. J. 2006. The “Anthropocene.” Pages 13-18 in E. Ehlers and T. Krafft, editors. Earth system science in the Anthropocene. Springer, Berlin Heidelberg, Germany. http://dx.doi. org/10.1007/3-540-26590-2_3

Daly, H. E. 2005. Economics in a full world. Scientific American 293:100-107. http://dx.doi.org/10.1038/scientificamerican0905-100

Daly, H. E. 2014. The negative natural interest rate and uneconomic growth. Center for the Advancement of the Steady State Economy, Arlington, Virginia, USA. [online] URL: http:// steadystate.org/the-negative-natural-interest-rate-and-uneconomicgrowth/print/

Diamond, J. 2005. Collapse: how societies choose to fail or survive. Viking Penguin/Allen Lane, New York, New York, USA.

Ehrlich, P. R., and A. H. Ehrlich. 2013. Can a collapse of global civilization be avoided? Proceedings of the Royal Society B | Biological Sciences 280:20122845. http://dx.doi.org/10.1098/ rspb.2012.2845

Ehrlich, P. R., P. M. Kareiva, and G. C. Daily. 2012. Securing natural capital and expanding equity to rescale civilization. Nature 486:68-73. http://dx.doi.org/10.1038/nature11157

Ehrlich, P. R., and R. E. Ornstein. 2010. Humanity on a tightrope: thoughts on empathy, family, and big changes for a viable future. Rowman \& Littlefield, Lanham, Maryland, USA.

Ferguson, B. C., R. R. Brown, and A. Deletic. 2013. A diagnostic procedure for transformative change based on transitions, resilience, and institutional thinking. Ecology and Society 18(4): 57. http://dx.doi.org/10.5751/ES-05901-180457

Fischer, J., R. Dyball, I. Fazey, C. Gross, S. Dovers, P. R. Ehrlich, R. J. Brulle, C. Christensen, and R. J. Borden. 2012. Human behaviour and sustainability. Frontiers in Ecology and the Environment 10:153-160. http://dx.doi.org/10.1890/110079

Folke, C. 2006. Resilience: the emergence of a perspective for social-ecological systems analyses. Global Environmental Change 16:253-267. http://dx.doi.org/10.1016/j.gloenvcha.2006.04.002 
Gardiner, S. 2011. A perfect moral storm: the ethical tragedy of climate change. Oxford University Press, Oxford, UK. http://dx. doi.org/10.1093/acprof:oso/9780195379440.001.0001

Gunderson, L. H., C. S. Holling, and S. S. Light, editors. 1995. Barriers and bridges to renewal of ecosystems and institutions. Colombia University Press, New York, New York, USA.

Hamilton, C. 2010. Requiem for a species: why we resist the truth about climate change. Allen \& Unwin, Sydney, Australia.

Hamilton, C. 2013. Earthmasters - the dawn of the age of climate engineering. Yale University Press, New Haven, Connecticut, USA.

Hansen, J., P. Kharecha, M. Sato, V. Masson-Delmotte, F. Ackerman, D. J. Beerling, P. J. Hearty, O. Hoegh-Guldberg, S.-L. Hsu, C. Parmesan, J. Rockstrom, E. J. Rohling, J. Sachs, P. Smith, K. Steffen, L. Van Susteren, K. von Schuckmann, and J. C. Zachos. 2013. Assessing "dangerous climate change": required reduction of carbon emissions to protect young people, future generations and nature. PLOS ONE 8:e81648. http://dx.doi. org/10.1371/journal.pone.0081648

Holling, C. S., and L. H. Gunderson. 2002. Resilience and adaptive cycles. Pages 25-62 in L. H. Gunderson and C. S. Holling, editors. Panarchy: understanding transformations in human and natural systems. Island Press, Washington, D.C., USA.

Intergovernmental Panel on Climate Change (IPCC). 2013. Climate change 2013: the physical science basis. T. F. Stocker, D. Qin, G.-K. Plattner, M. Tignor, S. K. Allen, J. Boschung, A. Nauels, Y. Xia, V. Bex, and P. M. Midgley, editors. Contribution of Working Group I to the Fifth Assessment Report of the Intergovernmental Panel on Climate Change. Cambridge University Press, Cambridge, UK.

Intergovernmental Panel on Climate Change (IPCC). 2014. Climate change 2014: mitigation of climate change. O. Edenhofer, R. Pichs-Madruga, Y. Sokona, E. Farahani, S. Kadner, K. Seyboth, A. Adler, I. Baum, S. Brunner, P. Eickemeier, B. Kriemann, J. Savolainen, S. Schlömer, C. von Stechow, T. Zwickel, and J. C. Minx, editors. Contribution of Working Group III to the Fifth Assessment Report of the Intergovernmental Panel on Climate Change. Cambridge University Press, Cambridge, UK.

Klare, M. T. 2012. The race for what's left: the global scramble for the world's last resources. Metropolitan Books, New York, New York, USA.

Lenton, T. M. 2012. Arctic climate tipping points. Ambio 41:10-22. http://dx.doi.org/10.1007/s13280-011-0221-x

Lenton, T. M., H. Held, E. Kriegler, J. W. Hall, W. Lucht, R. S. Rahmstorf, and H. J. Schellnhuber. 2008. Tipping elements in the Earth's climate system. Proceedings of the National Academy of Sciences 105:1786-1793. http://dx.doi.org/10.1073/pnas.0705414105

Lindblom, C. E. 1959. The science of "muddling through." Public Administration Review 19:79-88. http://dx.doi.org/10.2307/973677

Loorbach, D. 2010. Transition management for sustainable development: a prescriptive, complexity-based governance framework. Governance 23:161-183. http://dx.doi.org/10.1111/ j.1468-0491.2009.01471.x
Matthews, H. D., and K. Caldeira. 2007. Transient climatecarbon simulations of planetary geoengineering. Proceedings of the National Academy of Sciences 104:9949-9954. http://dx.doi. org/10.1073/pnas.0700419104

Meadows, D. H. 2008. Thinking in systems: a primer. Chelsea Green, White River Junction, Vermont, USA.

Meadows, D. H., J. Randers, and D. Meadows. 2004. Tools for the transition to sustainability. Chapter 8 in Limits to growth: the 30-year update. Chelsea Green, White River Junction, Vermont, USA.

Milanovic, B. 2012. Global income inequality by the numbers: in history and now: an overview. Policy Research Working Paper 6259. World Bank, Washington, D.C., USA. [online] URL: $\underline{\text { http:// }}$ elibrary.worldbank.org/doi/pdf/10.1596/1813-9450-6259

Moore, K. D., M. P. Nelson. 2010. Moral ground: ethical action for a planet in peril. Trinity University Press, San Antonio, Texas, USA.

Murtaugh, P. A., and M. G. Schlax. 2009. Reproduction and the carbon legacies of individuals. Global Environmental Change 19:14-20. http://dx.doi.org/10.1016/j.gloenvcha.2008.10.007

National Academy of Sciences USA. 1993. A joint statement by fifty-eight of the world's scientific academies. Population summit of the world's scientific academies. National Academy Press, New Delhi, India.

Olsson, P., L. H. Gunderson, S. R. Carpenter, P. Ryan, L. Lebel, C. Folke, and C. S. Holling. 2006. Shooting the rapids: navigating transitions to adaptive governance of social-ecological systems. Ecology and Society 11(1): 18. [online] URL: http://www. ecologyandsociety.org/vol11/iss1/art18/

Pearson, L. J., and C. J. Pearson. 2012. Societal collapse or transformation, and resilience. Proceedings of the National Academy of Sciences 109(30): E2030-E2031. http://dx.doi. org/10.1073/pnas.1207552109

Pielke, Sr, R. A., A. Pitman, D. Niyogi, R. Mahmood, C. McAlpine, F. Hossain, K. K. Goldewijk, U. Nair, R. Betts, S. Fall, M. Reichstein, P. Kabat, and N. de Noblet. 2011. Land use/land cover changes and climate: modelling analysis and observational evidence. Wiley Interdisciplinary Reviews: Climate Change 2:828-850. http://dx.doi.org/10.1002/wcc.144

Pimm, S. L., C. N. Jenkins, R. Abell, T. M. Brooks, J. L. Gittleman, L. N. Joppa, P. H. Raven, C. M. Roberts, and J. O. Sexton. 2014. The biodiversity of species and their rates of extinction, distribution, and protection. Science 344(6187):987. http://dx. doi.org/10.1126/science. 1246752

Planet Under Pressure. 2012. State of the Planet Declaration. Planet Under Pressure conference March 26-29 London, International Council for Science, Paris, France. [online] URL: http://www.planetunderpressure2012.net/pdf/state of planet_declaration. pdf

Ripple, W. J., J. A. Estes, R. L. Beschta, C. C. Wilmers, E. G. Ritchie, M. Hebblewhite, J. Berger, B. Elmhagen, M. Letnic, M. P. Nelson, O. J. Schmitz, D. W. Smith, A. D. Wallach, and A. J. Wirsing. 2014 $a$. Status and ecological effects of the world's largest carnivores. Science 343(6167): 1241484. http://dx.doi.org/10.1126/ science. 1241484 
Ripple, W. J., P. Smith, H. Haberl, S. A. Montzka, C. McAlpine, and D. H. Boucher. 2014b. Ruminants, climate change and climate policy. Nature Climate Change 4:2-5. http://dx.doi.org/10.1038/ nclimate 2081

Rockström, J., W. Steffen, K. Noone, Å. Persson, F. S. Chapin III, E. F. Lambin, T. M. Lenton, M. Scheffer, C. Folke, H. J. Schellnhuber, B. Nykvist, C. A. de Wit, T. Hughes, S. van der Leeuw, H. Rodhe, S. Sörlin, P. K. Snyder, R. Costanza, U. Svedin, M. Falkenmark, L. Karlberg, R. W. Corell, V. J. Fabry, J. Hansen, B. Walker, D. Liverman, K. Richardson, P. Crutzen, and J. A. Foley. 2009. A safe operating space for humanity. Nature 461:472-475. http://dx.doi.org/10.1038/461472a

Steffen, W., P. J. Crutzen, J. R. McNeill. 2007. The Anthropocene: are humans now overwhelming the great forces of Nature? Ambio 36:614-621. http://dx.doi.org/10.1579/0044-7447(2007)36[614:TAAHNO] 2.0.CO:2

Steffen, W., J. Grinevald, P. Crutzen, and J. R. McNeill. 2011. The Anthropocene: conceptual and historical perspectives. Philosophical Transactions of the Royal Society A | Mathematical, Physical \& Engineering Sciences 369:842-867. http://dx.doi.org/10.1098/ rsta.2010.0327

Steffen, W., K. Richardson, J. Rockström, S. E. Cornell, I. Fetzer, E. M. Bennett, R. Biggs, S. R. Carpenter, W. de Vries, C. A. de Wit, C. Folke, D. Gerten, J. Heinke, G. M. Mace, L. M. Persson, V. Ramanathan, B. Reyers, and S. Sörlin. 2015. Planetary boundaries: guiding human development on a changing planet. Science 1259855. http://dx.doi.org/10.1126/science.1259855

Tilmes, S., J. Fasullo, J.-F. Lamarque, D. R. Marsh, M. Mills, K. Alterskjær, H. Muri, J. E. Kristjánsson, O. Boucher, M. Schulz, J. N. S. Cole, C. L. Curry, A. Jones, J. Haywood, P. J. Irvine, D. Ji, J. C. Moore, D. B. Karam, B. Kravitz, P. J. Rasch, B. Singh, J.H. Yoon, U. Niemeier, H. Schmidt, A. Robock, S. Yang, and S. Watanabe. 2013. The hydrological impact of geoengineering in the Geoengineering Model Intercomparison Project (GeoMIP). Journal of Geophysical Research: Atmospheres 118:11,036-11,058. http://dx.doi.org/10.1002/jgrd.50868

Voß, J., and B. Bornemann. 2011. The politics of reflexive governance: challenges for designing adaptive management and transition management. Ecology and Society 16(2): 9. [online] URL: http://www.ecologyandsociety.org/vol16/iss2/art9/

Walker, B., C. S. Holling, S. R. Carpenter, and A. Kinzig. 2004. Resilience, adaptability and transformability in social-ecological systems. Ecology and Society 9(2): 5. [online] URL: http://www. ecologyandsociety.org/vol9/iss2/art5/

Weiten, W. 1994. Psychology: themes and variations. Thomson Brooks/Cole, Pacific Grove, California, USA.

Wenger, E. 2000. Communities of practice and social learning systems. Organization 7:225-246. http://dx.doi.org/10.1177/1350$\underline{50840072002}$

World Bank. 2012. Turn down the heat: why a $4^{\circ} \mathrm{C}$ warmer world must be avoided. World Bank, Washington, D.C., USA. [online] URL: http://www-wds.worldbank.org/external/default/ WDSContentServer/WDSP/IB/2012/12/20/000356161_20121220072749/ Rendered/PDF/NonAsciiFileName0.pdf
World Commission on Environment and Development. 1987. Our common future. Oxford University Press, Oxford, UK. 